KAROLINA WARZOCHA*

\section{Naturalne światlo w budownictwie mieszkaniowym początku XXI wieku. Standard czy luksus?}

\author{
Natural light in city housing of the XXI century. \\ Is this a standard or luxury?
}

Streszczenie

W ciągu ostatniego wieku znacznie polepszyły się warunki mieszkaniowe w polskich miastach. Problem powojennego de ficytu rozwiązala tzw. Wielka plyta. Rozlegle tereny przeznaczone pod budowę osiedi umozzliwily projektowanie budynków w Polsce, nastapita zmiana w sposobie projektowania osiedli, które zaczeły przybierać forme kolaży z przypadkowa zestawionych ze soba obiektów. Drastyczne zmnieiszenie odlegtósi miedzy budynkami oraz róże sposoby na maksymalne za budowanie działek inwestycyinych, negatywnie wpłyneły na jakość mieszkań. Celem artykułu jest zwrócenie uwagi na nisk stopień doświetlenia pomieszczén mieszkalny w w budynkach wiéch pokazuja liczne przykłady rozwiijajacych się krakowskich osiedli, problemem nie jest jedynie brak bezpośrednich promien słonecznych we wnetrzu mieszkania, ale brak nawet rozproszonego światta naturalnego. Pogarszającej się sytuacii sprzyja bezwzględny rynek nieruchomości oraz postępująca liberalizacja prawa budowlanego.

\section{Abstract}

Within the past century living conditions in Polish cities improved significantly. Post-war deficiency was solved by so called the pre-fab (concrete slab). Vast areas intended for housing estates enabled to design bulungs in considerable distances tha allowed the inhabitants to have intimacy and better lighting of the interiors. Along with the change of the political system in Poland, there was a change in designing housing estates that started to look like sets of objects randomly put together. Serious shortening of the distances between buildings and numerous ways to maximize managing investment plots had bad influence on the apartments quality. The aim of the article is to draw attention to the low level of lightening living space in multifamily buildings erected within the last decade. Various examples of developing Cracovian housing estates show tha Relentless property market and progressing liberalization of building law have been making the situation even worse.

Słowa kluczowe: światto naturalne, budownictwo mieszkaniowe, prawo budowlane, warunki techniczne

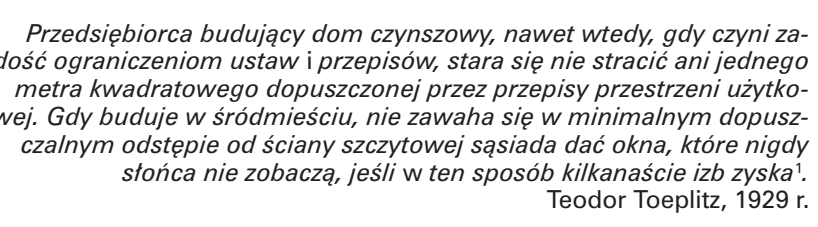

Rolą architekta jest kreowanie przestrzeni, która pozwoli użytkownikowi na pełny rozwój umysłowy i fizyczny, przy równoczesnych doznaniach estetycznych. W całym procesie projektowym najważniejszy powinien być człowiek i jego naturalne potrzeby. Pogodzenie aspektów technicznych i estetycznych z zagadnieniami biotechniki, psychologii i socjologii, jest dużym wyzwaniem, jakie stoi przed projektantem, ale jest to konieczne dla uzyskania należytego efektu.

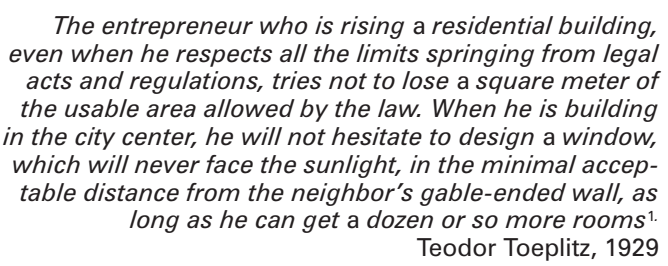

The role of the architect is to ceate the sace thapThe role of the architect is to create the space that ment and aesthetic experience at the same time. In the whole process of designing, the most im Reconcilement of technical and aesthetic points with biotechnical, psychological and sociologica portant factor in a man and man's natural needs.
Jednym z narzędzi, którym posługuje się architekt, jest światpomieszczen oraz wnetrz urbanistycznych. Zbawienny wpływ promieni słonecznych na zdrowie człowieka jest znany od wieków. Odpowiednia dawka nasłonecznienia zapobiega wielu chorobom, wspomaga dobre samopoczucie $i$ działa pobudzajaco. A to z kolei przekłada sie na lepsza wydainośc w miejscu pracy, pozytywnie wptywa na relacje spoteczne i ogólne zadowolonie. Stońce dzioła na czlowieka róm w sposób pośredni. Jest jednym z glównych czynników miwroksim posredni. Jest jednym z glownch czynnikow miości bakteriobójcze, co udowod. Zdając sobie sprawe z korzyści, jakie daje światło naturalne konieczność zapewnienia nasłonecznienia wnettrz mieszkalnych wydaje się sprawą oczywistą. Niestety, jak pokazuja liczne przykłady rozwijających się krakowskich osiedli, problemem nie jest jedynie brak bezpośrednich promieni słonecznych $w$ pomieszczeniu, ale brak nawet rozproszonego światta naturalnego. Sprzyja temu bezwzględny rynek nieruchomości oraz postępująca liberalizacja prawa budowlanego. Celem artykułu jest zwrócenie uwagi na niski stopień doświetlenia pomieszczeń mieszkalnych $\mathrm{w}$ budynkach wielorodzinnych wzniesionych w ciągu ostatniej dekady.

Pierwsze lata niepodległej Polski były okresem wielkiego kryzysu mieszkaniowego. Nieustanny napływ ludności ze wsi do miast w poszukiwaniu pracy, wysokie czynsze przy niskich wynagrodzeniach oraz brak pomocy ze strony państwa, spowodowały, że ludność zmuszona była mieszkać w urągających człowiekowi warunkach. Jedna piąta mieszkań była użytkowana przez 2-3 rodziny, a podnajmowanie łóżek osobom niespokrewnionym (tzw. sublokatorom) było na porządku dziennym. W latach największego kryzysu w polskich miastach na jedna izbe (wówczas słowo „izba" było równoznaczne z pomieszczeniem; kuchnię równiez liczono jako izbe) przypadały 4 osoby [9]. Organizuiace sie robotnicze spótziennie mieszkniowe próbowały poprawić syotucjcze spódzizypa nie 4 osoby

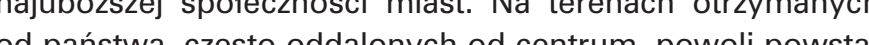

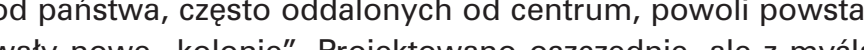
we now olepszych wark in

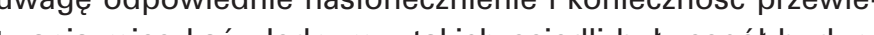
trzania mieszkan. Jedny z takich osiedi by zespol budynkow przy ullcy Podskanbihskiej w Warszawie. Jego mieszkaniec wspomina przeprowadzke do nowego lokum: Od 1922 roku, to jest od chwil przyjazdu do Warszawy, oczy nasze nie widziaty promienia stonca w mieszkaniu. A tu? To nie mieszkanie - to sanatorium. Jednak budownictwo społeczne, borykajajce się z ciągłym brakiem finansów, zdołało rozwiązać jedynie ułamek piętrzących się problemów mieszkaniowych. W ścisłych centrach miast nadal dominowała gęsta zabudowa kwartalna. W 1928 roku weszlo W życie pierwsze Prawo Budowlane niepodlegtej Polski [7]. Poza ogólnie sformułowaną koniecznością zapewnienia dostępu słońca do mieszkania (art. 15), okreslono maksymalną wysokosć budynku graniczącego z ulicą, równą szerokości tej ulicy (art. 182.). Wysokośc zabudowy wewnațz kwartałów mogła się- to face, yet essential to achieve the expected outcome. is man urban interiors. Benign ing the living space and a man's health has been known for centuries. Suf ficient amount of sunlight prevents several health problems, improves general sensation and works rousingly on mood. This in turn leads to higher efficiency at work, better social relations and genera Sappiness. The Sun affects a man also indirectly. Suntight is one of the dimensions of the interior midity of a rie. affects the temperature and huantibacteria activity that was proved by numerous scientific tests in XIX century [11].

Having realized all the above mentioned advantages of light, the need to provide well-lightened IVing space has become obvious. Unfortunately, as shown by many examples of developing Cracovan housing estates, the problem is not just in the all preperty market and progressing liberalientless building law have been making the situation even worse. The aim of the article is to draw attention to the low level of lightening living space in multifamily buildings erected within the last decade.

The first years of independent Poland were a pehiod of a great housing crisis. Continuous migrathon of people from villages into urban areas in and lack of fed, high rents along with low earnings orced to live in inumane conditions. One fift of the apartments were dwelled by 2-3 families while subletting beds to unrelated people( paying guests) was a common phenomenon. At the ine of the greatest crisis in Polish cities it was esWhated that for one chamber (the word "chamber" was related to a single room and the kitchen was was red to a sing room and 4 here 4 dwellers sociations of wavkers were trying to improve assituation of the poorest city societies. In the areas received from the city often located far from the city centers, new subdivisions were slowly being created. Designing was economical but taking into consideration better sanitary and health condilions, insolation and the need to ventilate space. On of the ensemble's residents remembers moving to a new apartment: Since 1922 which was the ime of arrival to Warsaw, our eyes haven't seen cial building, dealing with the lack of financing managed to solve just a fittle part of the growing problems. Close city centers were still dominated by the high-density quarterly housing. In 1928 the first construction law in the independent Poland need to provide access to sunlight into an apartment (art. 15), the maximum height of a building bordering with a street, equal to the width of the street, was set (art. 182). The height of the build- 
gać 1,5 odległości między budynkami (art. 183.), co znacznie pogorszyło doświetlenie zlokalizowanych tam pomieszczeń. Po II wojnie światowej warunki mieszkaniowe w polskich miastach stopniowo zaczęły się poprawiać. Problem powojennego deficytu rozwiązała technologia prefabrykacji wielkowymiarowych elementów żelbetowych tzw. wielka płyta. W tym okresie kilkukrotnie zmieniano Prawo Budowane oraz Warunki Techniczne i zawarte w nich przepisy dotyczące doświetlenia pomieszczeń mieszkalnych:

- 1961 r. [8] - Ustalenie minimalnego kąta padania światta 270 (\$93) - Ustalení miminalnego kąta padania swiatla mien między budynami rowny dwkrons sci [2]. Ponanto rozpoir wrania oraz mieszkań cztero- i więcej osobowych z jednostronną oraz mieszkan cztero- i więce
ekspozycja okien (\$88, pkt. 3).

- 1974 r. [14] - Na podstawie badań przeprowadzonych $1974 \mathrm{r}$. [14] - Na podstawle badań przeprowadzonych w ZSRR w latach 50. i 60. [11], wprowadzono minimalny czas nastonecznienia mieszkan równy 3 godziny w dniach rownonocy (21 marca i 21 wrzesnia); dotyczylo to 1 pokoju w mieszkaniach 4-osobowych oraz 2 pokoi w mieszkaniach większych. Minimalna odległość między budynkami wynosiła 1,8 ich wysokości [2].

- 1980 r. [4] - Zmniejszono minimalny odstęp między budynkami na równy ich wysokości (\$15, pkt. 3).

Należy mieć na uwadze, iż przedstawione powyżej minimalne wartości w praktyce często były zwielokrotniane. Rozległe tereny, jakie państwo przeznaczało pod budowe osiedli, umożliwiały projektowanie zabudowy w znacznych odstępach, co zapewniało mieszkańcom intymność i lepsze doświetlenie wnętrz. Np. minimalne odległości między budynkami na osiedlu Tysiąclecia w Katowicach (arch. H. Buszko i A. Franta; 1961r.) wynoszą 50 metrów [10]. Na krakowskim osiedlu przy ulicy Lipińskiego (rok budowy:
1984-1985) najmniejszy odstęp między równoległymi budynkami to 30,80 metrów, przy wysokości zabudowy 16,20 metróm. Natomiast runku pót bie wzdłuż osi N-S, co dodatkowo zwiększyło stopień dobie wzdłuz osi N-S,
świetlenia mieszkań
Proj.

Projektowanie osiedli odbywało się w sposób kompleksowy. Przeprowadzano analizy przepływu powietrza i nasłony. Przeprowadzano analizy przepływu powietrza i nasłometodą była tzw. linijka słońca Mieczysława Twarowskiego metodą była tzw. linijka stonca Mieczysława Twarowskiego stosowana do konca lat 80.). Standardem było projektowa-
nie mieszkań M4 (3 pokoje z kuchnią) z ekspozycją okien nie mieszkan M4 (3 pokoje z kuchnią) z ekspozycją okien
północ-południe lub wschód-zachód, co umożliwiało odpopółnoc-południe lub wschód-zachód, co umożliwiało odpowiednie nasłonecznienie i przewietrzenie wnętrz. Głębokość pomieszczeń rzadko przekraczała 4,5 metra 4 . Często spotykaną niedogodnoscią byly "ciemne "kuchnie. Mialo to związek z uproszczonym procesem prefabrykacji. Przykładem sa mieszkania w Superjednostce w Katowicach (arch. M. Król 1967-1972 r.) [10]. Obowiązujące wówczas Rozporządzenie [8] zezwalato na projektowanie malych, wentylowanych kuchni w mieszkaniach dwu- i trzyosobowych doświetlonych w sposób pośredni (\$93, ust. 6, pkt. 4). Po dwóch dekadach w Rozporządzeniu [4] zmieniono ten zapis i zezwolono ing inside of the quarter could have reached 1.5 of
the distance between the buildings (art. 183.) that of the rooms located there.

After the II World War, housing conditions began to improve gradually. The problem of the post-wa gies of high-size reinforced concrete elements, so called pre-fab concrete slab. At that time, the construction law and technical conditions that included regulations concerning lighting of living compartments, were changed a number of times: 1961 r. [8] - Setting the minimal angle of sunlight incidence for $27^{\circ}(\$ 93)$, that was equivalen
of the minimal distance between buildings equal to their doubled heights [2]. Besides, , the regulation prohibited planning apartments exposed to the North only ( $\$ 88$, subsection 1) and apartments four or more poli-personal with the on side window exposition(\$88, subsection 3). 1974 [14] - On the basis of the research carried out in $C C C P$ in fifties and sixties of the $X X$ century [11], the minimum time of sun exposition of a apartment, equal to 3 hours during the equinox
(March, $21^{\text {st }}$ - September, 21st) was introduced. That was related to 1 room in 4 person apartments and two rooms in bigger apartments. The ments and two rooms in bigger apartments. The for 1,8 of their heights [2].

1980 [4] The minimal distance between buildings was made equal to their heights (\$15, point 3$)$. It needs to be taken into account that the minim values presented above, were often multiplied in practice. Vast areas intended for housing estates tances that allowed the inhabitants to have intima$\mathrm{cy}$ and better lighting of the interiors. Eg. minima distances between buildings at Tysiaclecia Estate in Katowice (architect: H. Buszko i A. Franta; 1961) are 50 meters. [10]. At one of the Cracow estates at Lipińskiego street (built: 1984-85) the shortes distance between the parallel buildings is 30,80 meters, with the height of the buildings $16,20 \mathrm{me}$ ters. Moreover, the neighbouring building oriente another along the direction N-S that additionally extended the amount of apartment lighting ${ }^{4}$.

Planning housing estates was a complex process. The analyses of the airflow and sun exposition of buildings were carried out/ the most popula was the one that is called the sun ruler created by Mieczystaw Twarowski used until the eighties.) Planwith north-south or west-east window a kposition was a standard which allowed sufficient sunlight and insolation of the interiors. The depth of the interiors rarely exceeded 4,5 meters 5 . Blind (having no window) kitchens were a common inconvenience. It was connected with the simplified process of prefabrication. The example are apartments in Superjednostka in Katowice (arch. M. Krol; 1967-1972) [10]. The resolution [8] that was in force at that tim
allowed for planning small, isolated kitchens in twoor three- residential apartments well lightened in an indirect way ( $\$ 93$, sec. 6 , subsection 4). After two decades this law has been changed in the resolution na projektowanie wnęk kuchennych oswietlonych wyłącznie swiattem sztucznym, bez względu na wielkość mieszkania (§120, ust. 1, pkt. 3)

Obecnie, od kilku lat toczy sie spór o przyszłość osiedli z wielkiej płyty: burzyć czy modernizować? Krytycy wymieniają takie wady jak przestarzałe instalacje, brak izolacji akustycznej, mało elastyczny układ pomieszczeń, czy watpliwą estetyke zabudowy. Niekwestionowana zaleta tych osiedli sa poprzedzone licznymi analizami, układy urbanistyczne. Duzie odstepy miezlzy budynka zapewnia mieszkańcom intymnośc py między budynkami zapewniáa r

Wraz z przemini ustroju Wolsce, nastapita zmiana w spokrzybierać forme kek z prypalkowo zestawionych ze soba obiektow. Ryprywa bi inwe mizy. Kierujac sie checia jak najwekszego

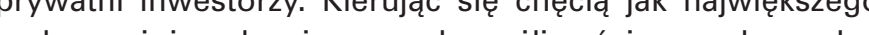
zysku, wciąz szuka się nowych mozliwossi na maksymaln zabudowanie dzilek. Wplywa to negatywnie na jakosć nowych mieszkan, jak rownież oddziałuje na budynki już istniejące.

Wprowadzone w 1994 roku nowe Prawo Budowlane [13] nakładało obowiazzek projektowania budynków $w$ sposób zapewniający warunki uzytkowe zgodne z przeznaczeniem obiektu, a wszczegolnosci wzakresie. oswietlenia (...) (art.5.1, pkt.7). Dodatkowo zapewniało ochronę uzasadnionych interesow osob trzecich, w tym ochronę przed pozbawieniem dopływu światta dziennego do pomieszczeń przeznaczonych na pobyt ludzi (art.5.2, pkt.2b). W 2003 roku wprowadzono zmiany do Ustawy [12], wykreslając z art.5.1 pojęcie oświetlenia $\mathrm{w}$ wymienionych warunkach użytkowych, jakie należy zapewnić. Natomiast w pkt. 9 tego artykułu, dotyczącym poszanowania (...) uzasadnionych interesów osób trzecich, nie wyjaśniono co należy rozumieć pod tym pojęciem ${ }^{5}$. Dało to zielone światto" deweloperom, w szczególności przy zabu"dowywaniu niewielkich wolnych działek między istniejacymi budynkami.

W tym czasie liberalizacji uległy również Warunki Techniczne. W tym czasie liberalizacj u (6] ustala minimana odleglość miedzy bud . 35 metróm (\$13, ust. 1, pt. 1). Dla budynów wyższch

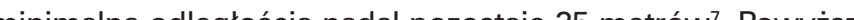
Warion wark nego dla okcy pomie pola widzia o krzesie odleglości te mogą być zmiejszenie o polowę w zabudowie śródmiejskiej (s13, ust. 4). Minimalny czas nastonecznienia pomieszczen miesz ulny wy nocy, w godzinach 7:00-17:00 (\$60, ust. 1). Wymóg dotyczy jednego pomieszczenia $w$ mieszkaniu wielopokojowym. W śródmiejskiej zabudowie uzupełniającej minimalny czas wynosi 1,5 godziny, natomiast w przypadku mieszkań jednopokojowych, na które jest obecnie duzy popyt, brak jest wymaganego czasu nasłonecznienia (\$60, ust. 2).

Coraz łagodniejsze prawo budowlane bezwzględnie wykorzystują deweloperzy. Powstają mieszkania głębokie, z jednostronną ekspozycją okien (nawet północną). Dostęp promieni słonecznych do mieszkan często uniemożliwiają same
[4] and it allowed for planning wall niches lighted with artificial light only regardless of the size of an partment (\$120, sec. 1 , subsection 3$)$.

or a few years there has been an argument concerning the future of the pre-fab housing estates: Critics list such faults as obsolete wiring lack of acoustic insulation, inflexible room planning or unaesthetic housing. One unconventional advantage of those housing estates are, preceded by numerous analyses, urban systems. Long distances between buildings provide intimacy and better lighting of the interiors.

Along with the change of the political system in Poland, there was a change in designing housing domly put together. Housing estates market has been mainly taken over by private investors. Being motivated by the desire to gain huge profits, investors have still been looking for the opportunities to develop on lots to the maximum. It has a negative mpact on the quality he existing buildings.

Newly introduced Building Law [13], has obliged the applied conditions in line with the building intention, especially in terms of light (...)" (art.5.1 subsection 7). Besides, the code has provided "reasonable protection of the third parties", including "protection from depriving a person of access to daylight in rooms intended for living" (art.5.2, subsection 2b). In 2003 there were some changes introduced to the Code[12], deleting from the article 5.1 applied conditions that should be providend Moreover, in point 9 . of the article concerning "respect (...) for the reasonable businesses of the third parties", it has not been explained what should be understood by this term. It gave way to developers, especially when it comes to housing small lots lef between the existing buildings,

At that time technical conditions have also been liberalized. Having been in effect since 2002 un between buildings as equal for the height of those buildings, yet it applies to buildings up to $35 \mathrm{me}-$ ters talls $(\xi 13$, sec. 1, subsection 1$)$. For buildings taller than that, the minimum distance has still been 35 meters. The above condition applies only to the view of angle $60^{\circ}$, designated for windows of the obscured room. Additionally, the distances may be (n) 4 . The minimum time of sunlight in ${ }^{9}(\$ 13$, dential space is 3 hours at equinox, between $7: 00$ 17:0010 ( $\$ 60$, sec. 1). This regulation applies to one room in multiroom apartments. In complementary downtown development, the minimal time of sun exposition is 1.5 hour, while in case of studio apartments (one bedroom) which have been highly desired recently, this factor is not defined $(\$ 60$, sec. 2$)$. Less and less strict construction law is ruthlessly window one-side exposition (even towards the North lare being built. The access of sunlight to the buildings is often limited or disabled by the forms of buildings themselves, which are planned 
formy budynków, których rzuty przyjmują kształty liter L, C, U. Nieodpowiednio usytuowane względem stron świata, generują permanentnie zacienione mieszkania. Zdjęcia satelitarne nowych osiedli mieszkaniowych ukazują, jak bardzo zmniejszyły się odległości między budynkami, w porównaniu do terenów, na których króluje wielka płyta. Sytuacja kształtuje się nieco lepiej, gdy całe osiedle projektuje jeden deweloper. Konieczność zapewnienia odpowiedniej ilości miejsc postojowych, komunikacji, terenów wspólnych dla mieszkańców, które uatrakcyjnią inwestycję, zwiększa przestrzeń między budynkami. Gdy osiedle powstaje na zasadzie: jeden budynek - jeden deweloper lub zabudowuje się wolną przestrzeń na istniejących od dekad osiedlach, dochodzi do kuriozalnych sytuacji, gdy odległości między 5-, 6-kondygnacyjnymi obiektami nie przekraczaja 10 metrów (il.4). Z pomoca przychodzi obecne Rozporzadzenie [6] i niejasna interpretacja „zabudowy śródmiejskiej", która zezwala na wznoszenie budynków $w$ odległości równej połowie ich wysokości. Pozbawia to użytkowników nie tylko światta, ale również poczucia bezpieczenstwa i intymności we własnym mieszkaniu. Jak zauważy ta M. Bartnicka w swojej publikacji [2] wróciliśmy tym samym do XIX wieku, gdy dostęp światła do mieszkań był znacznie ograniczony lub uniemożliwiony.

Ciekawym przykładem ilustrującym triki projektowe jest budynek wielorodzinny przy ul. J. Piltza w krakowskiej dzielnicy Dębniki. Powstał w latach 2009-2010. Posiada 5 kondygnacji, a jego formę najlepiej opisać jako połączenie galeriowca z zabudową kwartałową (il.1). Z zewnątrz budynek nie wyróżnia się niczym szczególnym, natomiast wewnątrz tworzy się „dziedziniec" z windami i biegami schodów. Zabudowa łączy w sobie wszystkie wady, jakie niosą ze soba obie formy. Galeriowce nigdy nie cieszyły się w Polsce dużym popytem. Okna kuchni czy sypialni zlokalizowane w przegrodach wzdłuż galerii odbieraja mieszkańcom poczucie komfortu i intymności. Podobnie jest w przypadku opisywanego obiektu O ile okna te spetniaja swoje funkcje w tradycyinym galeriowcu (dośmieteni i możliwość przewietrzenia minz kania), w przypadku budynku przy ut. Piltza (sa to okna kuchenne) wydaja sie być jedynie watpliwa dekoracj ścian. chen, wz prypaja sie być jedynie wątplwa dekoracja scian. dowe 1,2,3) wynosi $3,68 \mathrm{~m}$. Bieg schodów or az komu schodowe 1,2,3 wyna poziona, zapew calą tą szerokosc, pozostawiajac $63 \mathrm{~cm}$ wolnej przestrzen (il.2). Efektem tego sa miloszkan z zuch wiami, klónch okna nigdy nie spełnią podstawowej funkcji, jaką jest doświetlenie pomieszczenia. Sytuacja poprawia się w przypadku klatki
4. Szerokość "dziedzińca" wynosi tam 5,78 m. Po odjęciu komunikacji pionowej i poziomej, pozostaje przestrzeń o szerokości 2,46 $\mathrm{m}$. Nie rozwiązuje to jednak problemu na najniższych kondygnacjach. Dodatkowo, po roku użytkowania budynku, mieszkańcy zaczęli skarżyć się na zalegający śnieg na "dziedzincu" i schodach. W odpowiedzi spółdzielnia przekryła cały "dziedziniec" panelami z falistej pleksi o barwie mlecznej, co jeszcze bardziej ograniczyło dostęp światła oraz efektywność przewietrzania pomieszczeń. W całym obiekcie zaprojektowano 111 mieszkań, z czego 79 to lokale posiadające okna kuchenne wychodzące na "dziedziniec" (pozostałe into L, C or U shapes. Incorrectly situated buildings ons, they generate permanently dark apartments.

The satellite photographs of the new residentia areas show how much the distances between the where the prefabricated panels prevail. The situation is slightly better when the whole residentia area is designed by one developer. The need o area is designed by one developer. The need of
providing the necessary number of parking lots transport routes, communal grounds for all inhabitants that would make the investment more attractive increases the distances between the buildings. When the residential area is being created based empty space on the decades-old residential or the is constructed on, the bizarre situations occur. may happen that the distances between 5 or 6 -floo buildings are not more than 10 meters (ii.4). It this case the current Regulation [6] is useful as well as the unclear interpretation of the 'downtown development' that allows to construct buildings in the distance equal to the half of their altitude. deprives their users not only of light but also the it was mentioned by M. Bartnicka in her publication [2], we came back in this way to the $19^{\text {th }}$ century when the access of light to the apartments was significantly limited or completely prevented.

An interesting example which presents project tricks is an apartment block at Jana Piltza street in Cracow district Dẹbniki. It was built in 2009-2010. as a combination of a deck-acess bescribed a quarterly building (il.1). Outside of the building there is nothing peculiar, yet inside there is a yard with lifts and flights of stairs. The project has all th possible faults of both forms. Deck-access blocks have never been popular in Poland. The kitchen or bedroom windows located in slots along the galleries deprive the inhabitants of comfort and intimacy and so is in the case of the described object. Muc block (lighting and the possibility of apartment ventilation), yet in case of a building at Piltza street (it applies to kitchen windows only), they seem to be the only questionable wall decoration. The width of "the yard" at its narrowest point (staircase 1,2 and 3) is 3,68 $\mathrm{m}$ wide. Staircases and horizont flow providing the entrances to apartments, occupy almost the whole width, leaving only $63 \mathrm{~cm}$ of a free space (il.2). The effect are apartments never fulfill their function which is letting the ligh into the room. The situation is better in part 4 of the building. The width of the "yard" is 5,78 meters. Having taken away the vertical and horizontal communication ways, there is a space of $2,46 \mathrm{~cm}$ width left. Yet, that does not solve the problem at the lowest floors. In addition, after a year of using a building, the residents stated to complain about the snow lying too long at "the yard" and the stairs. yard with opal transparency panels made of plexiform plastic, which limited even more the access of sunlight and the effectiveness of room ventilation. to głównie mieszkania narożne). Podczas analizy mieszkania te podzielono na 3 grupy:

1) mieszkanie z oknem umożliwiającym doświetlenie pomieszczenia na poziomie akceptowalnym/ zadowalającym -25 mieszkań (głównie najwyższa kondygnacja oraz przestrzenie między klatkami schodowymi):

2) mieszkanie z oknem umożliwiającym doświetlenie pomieszczenia na niskim poziomie (uzależnione od stopnia zachmurzenia) - 15 mieszkań;

3) mieszkanie z oknem uniemożliwiającym doświetlenie pomieszczenia - 39 mieszkań.

Większość $z$ tych okien (wyjątek stanowi najwyższa kondygnacja) jest przesłonięta całą dobę. Mieszkańcy wykorzystuja w tym celu wszelkiego rodzaju zasłony, rolety, żaluzje oraz materiały nieprzepuszczające światta, naklejane na oszklenie. Część kuchni obecnie połączona jest z pokojem dziennym ${ }^{10}$ co pozwala wykorzystywać okna przeciwlegtej ściany miesz kania. Jednak przy głębokości pomieszczenia wynoszące 6,60-7,20 m (dodatkowo zwiększa ją balkon o głębokości $1,8 \mathrm{~m})$, konieczne jest stosowanie sztucznego oświetlenia. Mieszkania zostały wykupione $\mathrm{w}$ trakcie trwania robót budowlanych, więc istnieje obawa, iż nie wszyscy mieszkańcy byli świadomi czekających ich utrudnień. Budynek jest rów nież przykładem wykorzystania zapisu dotyczącego mieszkan jednopokojowych ([6] §60, ust. 2). Zaprojektowano w nim 4 mieszkania jednopokojowe $z$ jednostronną, północną eks pozycją, co uniemożliwia nasłonecznienie mieszkania niezależnie od pory roku.

Jednym z powszechnych sposobów na uzyskanie jak największej powierzchni użytkowej budynku jest projektowanie wąskich i głẹbokich pomieszczen. W efekcie powstają ciemne kuchnie, jadalnie oraz nieustawne i niedoświetlone pokoje. W celu zbadania skali problemu przeanalizowano 10 obiektów, których budowa rozpoczeła się w 2015 roku lub później w ramach czterech różnych inwestycji deweloperskich"11, na terenie krakowskiej dzielnicy Dębniki.

Tabela 1. Opracowanie wtasne / Self-analyses

\begin{tabular}{|c|c|c|c|c|c|}
\hline Budynek & $\begin{array}{c}\text { Mieszkania } \\
\text { z pomieszzzeniami } \\
\text { o gtebekokości do } 7 \mathrm{~m} \\
\text { The number and the } \\
\text { percentage } \\
\text { of apartments } \\
\text { up to } 7 \mathrm{~m} \text { deep }\end{array}$ & $\begin{array}{c}\text { Mieszkania } \\
\text { z pomieszczeniem } \\
\text { o glębokososci powyżej } \\
7 \mathrm{~m} \\
\text { Apartments with } \\
\text { a room more than } \\
7 \mathrm{~meters} \text { deep }\end{array}$ & $\begin{array}{c}\text { Mieszkania } \\
\text { z pomieszczeniem } \\
\text { o getebokości } \\
\text { powyzizj } 7.5 \mathrm{~m} \\
\text { Apartments with } \\
\text { a room more than } 7.5 \\
\text { meters deep }\end{array}$ & $\begin{array}{l}\text { Mieszkania } \\
\text { z pomieszczeniem } \\
\text { o geebeokości } \\
\text { powyzej } 8 \mathrm{~m} \\
\text { Apartments with } \\
\text { a room more than } \\
8 \text { meters deep }\end{array}$ & $\begin{array}{l}\text { llość } \\
\text { mieszká } \\
\text { w budynku } \\
\text { Number of } \\
\text { apartments } \\
\text { in a build- } \\
\text { ing }\end{array}$ \\
\hline 1 & $36(51,4 \%)$ & - & $34(48,6 \%)$ & - & 70 \\
\hline II & $44(59,5 \%)$ & $18(24,3 \%)$ & $12(16,2 \%)$ & - & 74 \\
\hline III & $42(58,3 \%)$ & $4(5,6 \%)$ & $24(33,3 \%)$ & $2(2,8 \%)$ & 72 \\
\hline IV & $36(54,5 \%)$ & $6(9,1 \%)$ & $24(36,4 \%)$ & - & 66 \\
\hline $\mathrm{v}$ & $25(46,3 \%)$ & $29(53,7 \%)$ & - & - & 54 \\
\hline $\mathrm{VI}$ & $20(23,8 \%)$ & $32(38,1 \%)$ & $4(4,8 \%)$ & $28(33,3 \%)$ & 84 \\
\hline VII & $24(29,6 \%)$ & $20(24,7 \%)$ & $15(18,5 \%)$ & $22(27,2 \%)$ & 81 \\
\hline VIII & $24(27,3 \%)$ & $52(59,1 \%)$ & $4(4,5 \%)$ & $8(9,1 \%)$ & 88 \\
\hline IX & $16(44,4 \%)$ & $12(33,3 \%)$ & $2(5,6 \%)$ & $6(16,7 \%)$ & 36 \\
\hline$x$ & $73(42,9 \%)$ & $60(35,3 \%)$ & $27(15,9 \%)$ & $10(5,9 \%)$ & 170 \\
\hline
\end{tabular}

In the whole object, there have been designed 111 apartments, out of which 79 are the apartments having kitchen windows facing "the yard". The res are mainly apartments located on the corners of were divided into three categories:

1. An apartment with a window allowing for acAn apartment with a window allowing for ac-
ceptable level of insolation - 25 apartments mostly the highest floor and the space between the staircases).

An apartment with a window allowing for low level of insolation (depending of the level of cloudiness) - 15 apartments.

in The majority of the windows

est floor) is shaded all day long. To to the highresidents use all sorts of curtains, blinds and view less sticky materials are stuck to the glass surfaces. Some of the kitchens are joined to the living copposite wall to let the lo use the windows on the

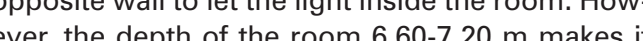
ecessary to use artificial light all day long. The apartments were bought while the building works were still in progress so there is a concern that the owners were not aware of the forthcomin

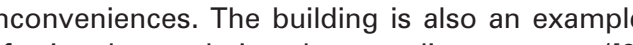
(60) ( the north, which makes sufficient insolation imossible regardless of the season.

One of the most popular ways to get the biggest possible usable area is designing narrow and deep poms. As a result, there are created dark kitchens abe he been ats a d of which grounds were broke ing investments ${ }^{12}$ in the Cracow district of Debnik. and dining rooms, and impractical when it comes 作 

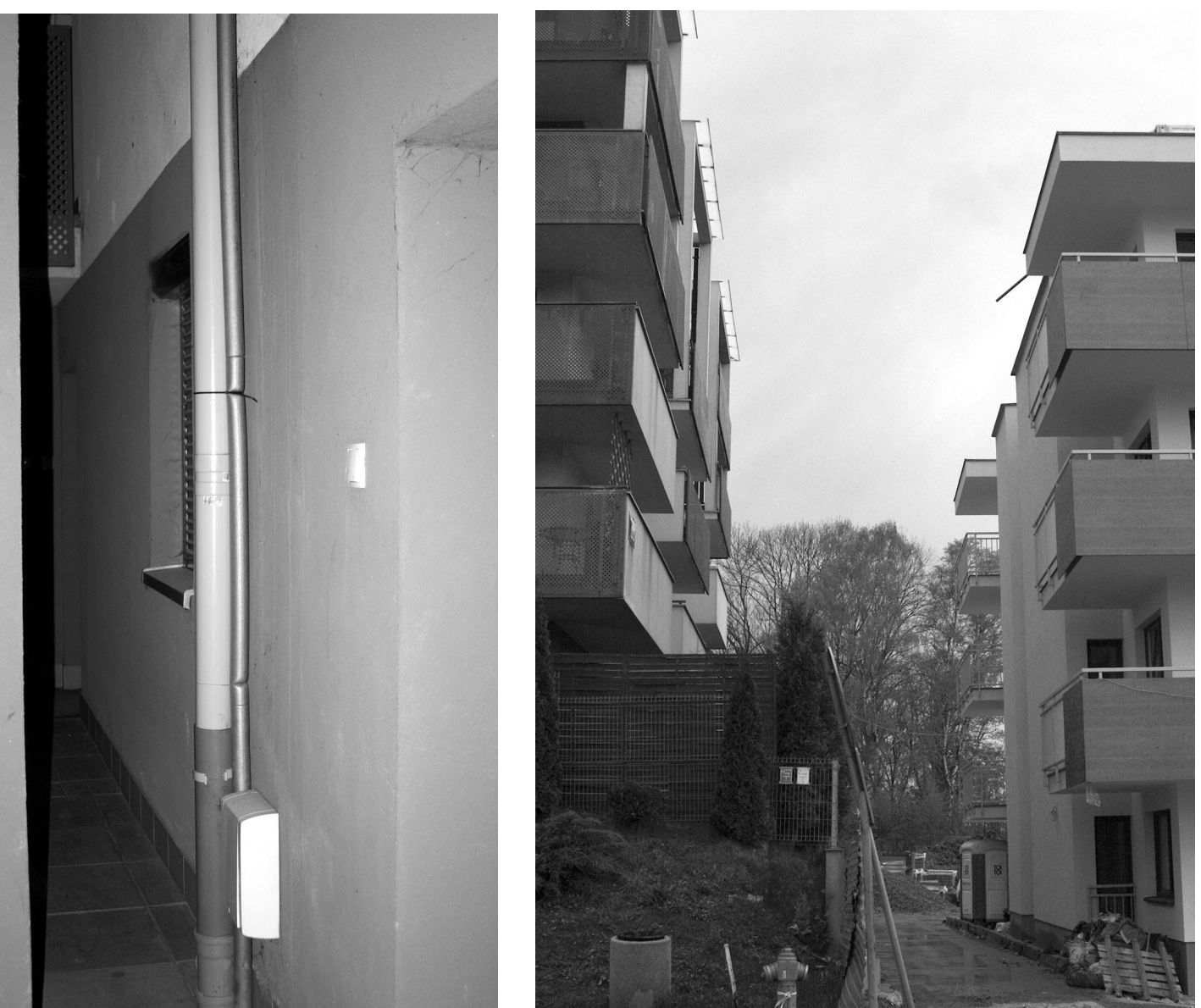

Powszechnie przyjmuje się, że światło naturalne doświetla wnętrze do 6 metrów geebokosci. Analizując mieszkania mając na uwadze realia, jakie obecnie panują w polskim budownictwie mieszkaniowym, akceptowalną granice zwiększono do 7 metrów. Mieszkania podzielono na 4 grupy w zależności od głebokości pomieszczeń. Pierwsza grupe - mieszkania z pomieszczeniami nieprzekraczajacymi $7 \mathrm{~m}$ głebokości - uznano za mieszania doświetlone. Pozostate w których przynaimniej jedno pomieszczenie, takie jak pokj dzienny, pokój dzienny z anoksem kuchennym, pokoj, ghebsze niz, koleno: $7 \mathrm{~m}, 7.5 \mathrm{~m}, 8 \mathrm{~m}, z a$ mieszania dośmietlon ke Cem analizy bylo zbadanie procentowego udzicu mieszan nedoswetonych wedug powyzsych kryteriów. Wyiki ziedoswiellonych wedug powyzszych nedón Wyniki zestawiono w tabeli 12 . Pokazuje one, iz wsysticto mieszkania często stanowią ponad polowę wszystkich lokali w budynku. W najgorszym przypadku jest to nawet $75 \%$ mieszkań.

Analizując układy mieszkań oferowanych przez deweloperów, zaobserwowano również inne praktyki projektowe, które generują niedoświetlone przestrzenie, m.in. projektowanie pomieszczeń na planie litery $L$ skierowanej do wnętrza mieszkania. W ten sposób maksymalnie wykorzystuje sie powierzchnię użytkową lokalu, kosztem uzyskania kuchni bądż jadalni, do której światło nigdy nie dotrze.

Obecna sytuacja na polskim rynku nieruchomości nie powinna zaskakiwać. Przewidziat ja Teodor Toeplitz już w 1929

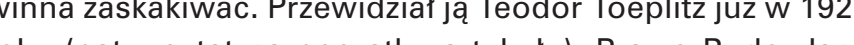
wo Budowlane kcie dostępu światta do mieszkania, a zapisy w Warunkach Technicznych daja dużą swobodę interpretacji. Bezwzględnie wykorzystuja to deweloperzy oferując mieszkania niedoświetlone, bez możliwości przewietrzania, odbierające poczucie intymności. Posiadanie wlasnego mieszkania to dla wielu Polaków zwłaszcza młodych, duze szczęscie, ale posiadanie własnego, dobrze doświetlonego mieszkania, to dziś prawdziwy luksus.

PRZYPISY

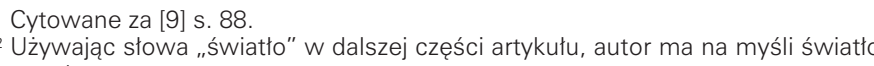
naturalne.
3 [ 9 s. 109
4 Wszelkie

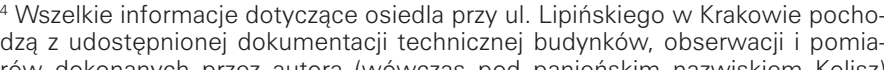

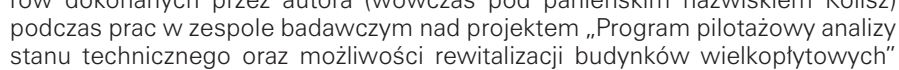
oraz nad projektem rewitalizaciji osiedlla Ruczaj-Zaborze w ramach porozumienia
miedzy Politechnika Krakowska a Prezydentem Miasta Krakowa w 2014 roku. W wyniku tych prac ukazały się publikacje [3] i [15]. "Dla pryykadu: maksymalna glebokosc pomieszczenia w punktowcu przy ul. Lipińskiego w Krakowie to $4,67 \mathrm{~m}$ (pow. pokoju $13,17 \mathrm{~m}$ ): glebokoości po
mieszzzeñ w budynkach segmentowo-klatkowych na tym osiedlu nie przekra Czaja 3,5 metra.
6 Zestawienie arty artykutów obu Ustaw - [1] tabela W tym okresie z Rozporzadzenia [6] usunieitoto zapis o minimalnej odlegtości
wynoszacej 20 metrón między budynkami mieszkalnymi wielorodzinnymi oraz

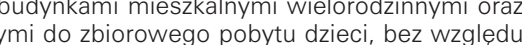
Dla porównania: w Rozzorzadzeniu [5] z 1994 roku, minimalna odlegtość mię-

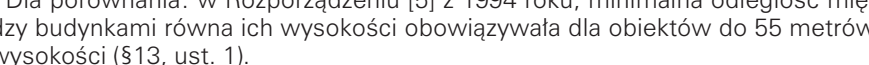
o Problem interpretacji ,zabudowy śródmiejskiej" został poruszony w publi-
kacij [1].
It is believed that sunlight reaches 6 meters deep inside a room. Analyzing apartments and taking into account the situation in the Polish housing construction, the acceptable margin has been lengthinto four 7 moups Apending on the beent classtified group - the apartments up to 7 meters deep, have been considered as well lightened. The rest, where there is at least one room (i.e. the living room, living room combined with a kitchen,) deeper than in turn: 7 meters, 7.5 meters, 8 meters, is considered as poorly lightened. The aim of the analysis was to find out the percentage of poorly lightened mentioned classification. The results are shown the Table 13. They show that in may cases porly lightened apartments make for over a half of all apartments in a building. The worst result is up to 75 percent of all apartments in the building.

When analyzing the layout of the apartments of fered by the developers, other design practices have also been observed, which generate poorly lightened spaces, such as designing L-shaped af the building is maximally. In this way the space the sunlight will never reach the kitchen or the dining room in the apartment.

The current situation on the Polish construction market should not be surprising. It has been predicted by Teodor Toeplitz in 1929 (go to the quote at the beginning of the article). The Construction law does not protect the businesses of the thir parties when rit comes to the access of light to the Technical Conditions leave a lot of freedom in interpretation. Investors take advantage of that fact and offer poorly lightened apartments, with not possibility of ventilation, depriving its residents of their privacy. Owning an apartment is a blessing for many Poles, especially the young, yet owning a well lightened apartment is sheer luxury.

ENDNOTES

Quoted from [9] page 88.
Using the word 'light' in. the author means 'natural light'. An information concerning the housing estate at Lipínskiego
street in Cracow come from the facilitated technical documents of the buildings, observations and measurement made
by the author (then known under the maiden name Koliszz
during the work in a research team over the project called." during the work in a research team over the project called The pilot analysis program of technical condition and revita
lization possibilititis of or re-fab buildings" and over the project of revitalizing of the housing estate Ruczai-zaborze within the the Mayor of the Cracow in 2014. As a result of thos
of work, the papers [3] i $[15]$ have been published. For example: the maximum depth of a room at a tower the room is $13,17 \mathrm{~m}$ ); the depth of the rooms in segmental-
cellular buildings at this housing estate does not exceed A collection of articles from both acts of law - [1] table 1 . At that time, the record [6] concerning the minimal distar ce between housing multit household buildings totaling 20
meters and buildings with the rooms intended for corporate staving of children regardless of their height, has been can8 To compare: In the regulation [5] from 1994, the minimal
distance between buildings equal to their height regarded distance between buildings equal to their height regard
the objects up to 55 meters tall (\$13, subsection 1$)$. 
10 Dla porównania: wg Rozporządzenia [5] z 1994 roku, wymóg minimalnego czasu nasłonecznienia wynoszący 3 godziny, musiał być spełniony w godzinach 8:00-16:00, co było korzystniejsze dla użytkowników pomieszczeń ze względu na wysokość słońca w naszych szerokościach geograficznych.

${ }^{11}$ W niektórych przypadkach zaprojektowane ścianki działowe pełne między kuchnią a pokojem dziennym zastąpiono przegrodą z luksferów lub połączenia pomieszczeń dokonano na prośbę właścicieli jeszcze w trakcie budowy.

12 Lista analizowanych inwestycji została podana wydawnictwu i tam zdeponowana.

13 Analiza przeprowadzona na podstawie ofert deweloperskich zamieszczonych na stronach internetowych poszczególnych inwestycji.

\section{LITERATURA:}

[1] Bartnicka M.: Doświetlenie wnętrz mieszkalnych. Monografia konferencyjna: Badania Interdyscyplinarne w Architekturze. Tom 1 WA Politechniki Śląskiej, Gliwice 2015, s. 136-146.

[2] Bartnicka M.: Wczoraj, dziś i jutro w promieniach słonecznych

(?). Czasopismo Techniczne z. 15. Architektura z. 7-A2, Kraków 2010

[3] Kolisz K., Kłosak A., Bucka A., Ziarko B.: Możliwości rewitalizacji układu przestrzennego zespołu mieszkaniowego z budynkami wielkopłytowymi na przykładzie osiedla Ruczaj-Zaborze w Krakowie. Przegląd Budowlany nr 6/2015, Kraków 2015.

[4] Rozporządzenie MAGTiOŚ z dnia 3 lipca 1980 r. w sprawie warunków technicznych, jakim powinny odpowiadać budynki. Dz.U. 1980 Nr 17, poz. 62.

[5] Rozporzadzenie MGPiB z dnia 14 grudnia 1994 r. w sprawie warunków technicznych, jaki powinny odpowiadać budynki i ich usytuowanie. DZ.U. 1995 Nr 10, poz. 46

[6] Rozporządzenie Ministra Infrastruktury z dnia 12 kwietnia 2002 r. W sprawie warunków technicznych, jakim powinny odpowiadać budynki i ich usytuowanie. Dz.U. $2002 \mathrm{Nr} 7$, poz. 690.

[7] Rozporządzenie Prezydenta Rzeczypospolitej z dnia 16 lutego 1928 r. o prawie budowlanem i zabudowaniu osiedli. Dz.U. z 1928r. Nr 23, poz. 202

[8] Rozporządzenie Przewodniczącego Komitetu Budownictwa, Urbanistyki i Architektury z dnia 21 lipca 1961 r. w sprawie warunków technicznych, jakim powinny odpowiadać obiekty budowlane budownictwa powszechnego. Dz.U. $1961 \mathrm{Nr}$ 38, poz. 196

[9] Springer F: 13 pięter. Wyd. Czarne, Wołowiec 2015.

[10] Springer F.: Źle urodzone. Wyd. Karakter, Kraków 2011.

[11] Twarowski M.: Słońce w architekturze. Wydanie 4. Wyd. Arkady, Warszawa 1996

[12] Ustawa z dnia 27 marca 2003 r. o zmianie ustawy - Prawo budowlane oraz zmianie niektórych ustaw. Dz.U. 2003 Nr 80, poz. 718. [13] Ustawa z dnia 7 lipca 1994 r. Prawo Budowlane. Dz.U. 1994 Nr 89, poz. 414

[14] Zarządzenie nr 9 MGTiOŚ z dnia 29 stycznia 1974 r. w sprawie wskaźników i wytycznych dla terenów mieszkaniowych w miastach. Dz.Bud. nr 2 z dnia 2 lutego 1974 r., poz. 2.

[15] Ziarko B., Bucka A., Kolisz K., Kłosak A.: Możliwości rewitalizacji formy architektonicznej i układu funkcjonalno-przestrzennego budynków wielkopłytowych na przykładzie osiedla Ruczaj-Zaborze w Krakowie. Przegląd Budowlany nr 6/2015, Kraków 2015.
9 The problem of interpretation of the "downtown development" has been mentioned in the paper [1]

10 To compare: According to the resolution [5] z 1994, a period of 3 hours as the minimum time to sunlight exposition requirement, had to be fulfilled between 8.00-16.00 that was more beneficial for the residents because of the height of the sun in our latitude.

${ }^{11}$ In some cases, full division walls between the kitchen and the living room were replaced by the glass brick compartments or the combination of rooms has been made at the owners' request while the building works were in progress.

12 The list of the analyzed investments has been revealed and lodged at the publisher's.

${ }^{13}$ The analysis was conducted on the basis of the development offers found at the websites of the investments.

\section{BIBLIOGRAPHY:}

[1] Bartnicka M.: Doświetlenie wnętrz mieszkalnych. Monografia konferencyjna: Badania Interdyscyplinarne w Architekturze. Tom 1, WA Politechniki Śląskiej, Gliwice 2015, s. 136-146.

[2] Bartnicka M.: Wczoraj, dziś i jutro w promieniach słonecznych (?). Czasopismo Techniczne z. 15. Architektura z. 7-A2, Kraków 2010.

[3] Kolisz K., Kłosak A., Bucka A., Ziarko B.: Możliwości rewitalizacji układu przestrzennego zespołu mieszkaniowego z budynkami wielkopłytowymi na przykładzie osiedla Ruczaj-Zaborze w Krakowie. Przegląd Budowlany nr 6/2015, Kraków 2015.

[4] Rozporządzenie MAGTiOŚ z dnia 3 lipca 1980 r. w sprawie warunków technicznych, jakim powinny odpowiadać budynki. Dz.U. $1980 \mathrm{Nr} 17$, poz. 62.

[5] Rozporządzenie MGPiB z dnia 14 grudnia 1994 r. w sprawie warunków technicznych, jaki powinny odpowiadać budynki i ich usytuowanie. DZ.U. $1995 \mathrm{Nr}$ 10, poz. 46.

[6] Rozporządzenie Ministra Infrastruktury z dnia 12 kwietnia 2002 r. w sprawie warunków technicznych, jakim powinny odpowiadać budynki i ich usytuowanie. Dz.U. $2002 \mathrm{Nr}$ 7, poz. 690.

[7] Rozporządzenie Prezydenta Rzeczypospolitej z dnia 16 lutego 1928 r. o prawie budowlanem i zabudowaniu osiedli. Dz.U. z 1928r. Nr 23, poz. 202.

[8] Rozporządzenie Przewodniczącego Komitetu Budownictwa, Urbanistyki i Architektury z dnia 21 lipca 1961 r. w sprawie warunków technicznych, jakim powinny odpowiadać obiekty budowlane budownictwa powszechnego. Dz.U. $1961 \mathrm{Nr}$ 38, poz. 196

[9] Springer F.: 13 pięter. Wyd. Czarne, Wołowiec 2015.

[10] Springer F.: Źle urodzone. Wyd. Karakter, Kraków 2011.

[11] Twarowski M.: Słońce w architekturze. Wydanie 4. Wyd. Arkady, Warszawa 1996.

[12] Ustawa z dnia 27 marca 2003 r. o zmianie ustawy - Prawo budowlane oraz zmianie niektórych ustaw. Dz.U. 2003 Nr 80, poz. 718.

[13] Ustawa z dnia 7 lipca 1994 r. Prawo Budowlane. Dz.U. 1994 Nr 89, poz. 414.

[14] Zarządzenie nr 9 MGTiOŚ z dnia 29 stycznia 1974 r. w sprawie wskaźników i wytycznych dla terenów mieszkaniowych w miastach. Dz.Bud. nr 2 z dnia 2 lutego 1974 r., poz. 2.

[15] Ziarko B., Bucka A., Kolisz K., Kłosak A.: Możliwości rewitalizacji formy architektonicznej i układu funkcjonalno-przestrzennego budynków wielkopłytowych na przykładzie osiedla Ruczaj-Zaborze w Krakowie. Przegląd Budowlany nr 6/2015, Kraków 2015. 